\title{
How Do Paternalistic Leader Behaviors Shape Xenophobia in Business Life?
}

\author{
Olcay Okun ${ }^{1}$ Cem ŞEN ${ }^{2}$ Korhan Arun ${ }^{3 *}$, \\ ${ }^{1}$ Ministry of National Defense, Ankara, Turkey \\ ${ }^{2}$ Ministry of National Defense, Ankara, Turkey
}

${ }^{3}$ Faculty of Economics and Administrative Sciences, Namık Kemal University, Tekirdag, Turkey

\begin{tabular}{l} 
Keywords: \\
Paternalistic Leadership, \\
Xenophobia, Social Identity \\
Theory \\
Received \\
06 July 2020 \\
Received in revised form \\
17 July 2020 \\
Accepted \\
18 July 2020 \\
\hline
\end{tabular}

*Correspondence

korhanarun@gmail.com

\begin{abstract}
Migration movements transform business life because they have more social aspects than geographic or numerical interactions. This paper reviews empirical research better to understand the effect of leadership in the process of xenophobia in the work environment from social identity theory perspective. Leadership as a social contextual factor is critical for understanding in determining individuals' internalization of particular cultural identities regarding to social identity theory. From that point of view, paternalistic leadership can be an ideological motive to affect the social order by internalization of inferiority among members by family-like relations and involving personal lives and expecting interpersonal favors. The sample of the study was chosen from Gaziantep, with a total number of 634 employees and 78 firms, where the immigrant population is dense. Results revealed that paternalistic leadership and xenophobia dimensions were relatively different in that specific sector. In a nutshell, paternalistic leadership does not significantly affect the personal and political hostility factor of xenophobia as social group theory predicted. However, it affects the cultural and identity dimensions of xenophobia self-idealization. Implications for theory and practice alongside limitations are discussed.
\end{abstract}

CCIKD Publishing

\section{Introduction}

Xenophobia agenda has emerged around the business life due to the rise of anti-immigrant prejudice in recent years (Yakushko, 2009). Xenophobia can result from members of oppressed and nonoppressed groups (inter group-out group process) in organizations (Clark et al., 1999). Because group membership is generally defined by foundational insights and social context of the groups 
(Tajfel et al., 1971; Uhl-Bien et al., 2014). In other words, social identity theories define the meaning of membership within groups (Reicher et al., 2005; Yukl, 2013). In such contexts, a collective spirit tends to dominate, and members may be treated differently by the leader; thus, paternalistic leader-member relations are perceived to be more effective (Graen, 2005). As a result, leadership is one of the most critical social contextual factors that determine individuals' internalization to the group, so of particular social identities (Haslam \& van Dick, 2011) within organizations.

Group membership, a key concept for xenophobia, is often not voluntary in organizational contexts. Leadership can be a major factor in ensuring individuals learn shared behavioral or psychological aspects of the group by socialization processes according to self-categorization theory (Guimond, 2000; Turner et al., 1979). In other words, merely belonging to a group for any reason -for example, the example defined by the leader seems to be sufficient to promote a feeling of being a part of that group (Kwantes \& Glazer, 2017). Therefore, leadership can be at the reason of being susceptible to group influences and being a part of a given group culture (Smith et al., 2005). Consequently, these group influences defined by the leader, especially an effective paternalistic leader in some national cultures, could promote or thwart racism, namely xenophobia.

One of the negative consequences of the increasing immigrant effect with the social identity crisis is xenophobia in business life (Sheridan, 2006; Yakushko, 2009). Therefore, it is of utmost importance to examine the perception of xenophobia that may adversely affect the effectiveness of the employees in various aspects and to eliminate this perception or to reduce its effects to a negligible level. Today, even if all human beings are immigrants within a globalized economy, the concept 'immigrant' is a demographic, geographical, or socio-geographical term but also considered with the duration of habitation (Morén-Alegret, 2002; Morén-Alegret \& Wladyka, 2020).

Group identities and goals among group members may be related to leadership within groups (Yammarino, 2013). Social identity theory perspective indicates that with experience and increased group identification, groups develop their unique prototype of an effective leader (Hogg, 2010; Hogg, 2001). In most past studies on social identity theory, researchers used laboratory experiments with small convenience samples of students and tested the effect of a temporary, artificially created identity on a contrived issue (Neuman, 2014). Nevertheless, the effects of leaders to xenophobia from the group or social perspective have not been clearly explained in the literature.

Paternalistic leadership (PL) can be an ideological motive to justify the existing social order by internalization of inferiority among members but not primarily on the "implicit, nonconscious level of awareness" (Jost et al., 2004) rather family-like relations by involving personal lives and expecting interpersonal favors (Aycan, 2006b; Pellegrini \& Scandura, 2008). In this context, our study was designed to observe the effect of paternalistic leaders on xenophobia by reassuring group self and its boundaries but not from the national level as in a phenomenological approach, preferably at the organizational level. Even if, in terms of diversity, social identity theory suggests that simply having diversity in a group and out-group makes that identity salient in peoples' minds (Uhl-Bien et al., 2014), the theory does not explain the process and antecedents. Furthermore, in cultures which each individual achieves social identity through interdependence and mutual recognition, a specific type of leadership is an important topic to research. Hence, it has been a considerable gap in the literature and potentially important research point to investigate whether xenophobic views of the social world are the result of a fight for scarce jobs or a culture clash resulting from the discourse of exclusion and devaluation which organizational and managerial 
leaders generate. Therefore, with this research we aim to contribute to theory and practice. First, the research adds contribution by refining the national-level phenomenological approach to an organizational-level perspective. Second, we examine the effect of paternalistic leadership on the xenophobia, to our knowledge never researched before. Third, the leadership concept is related to the cultural construct of xenophobia literature to identify necessary conditions for using a PL behavior effectively; different than descriptive theories to explain why PL behaviors occur in which collective structures related to other factors than the leaders. The sample of the study was chosen from Gaziantep, where the immigrant population is dense. Given this untapped research area, the primary motivation for this study comes from the need to explore the underlying paternalistic leadership associated with xenophobia. Our research question has been determined within the framework discussed; even if social identities primarily in a cultural context, how the identity members feel concerning their organization as work-related identity affects xenophobia.

\section{Theory and Hypotheses}

\section{Xenophobia}

The term xenophobia derives from the Greek xenos (foreigner or stranger) and phobos (fear or aversion). It is generally used to describe the fear of, contempt for, or aversion to foreigners and, more broadly, people, values, customs, beliefs, and even artifacts differing from those of one's own culture (Duckitt, 2010). From a group perspective xenophobia, is the feeling described by adherence to a tribe, clan, and similar racial group (Yakushko, 2009). People inevitably develop a strong loyalty to their ethnic groups and discriminate against foreigners. Xenophobia has several dimensions which can be collected as the cultural and identity dimensions and the personal and political fear dimensions (van der Veer et al., 2011). Xenophobia has been observed experimentally in a large number of species, with prominent regional and/or relatively closed social groups organized on a hierarchical basis (Dennen, 2000). Expressions of xenophobia range from prejudicial attitudes and explanations to forms of corporate or social exclusion, harassment, interpersonal, and collective violence (Asia-Pacific, 2001).

Xenophobia is fear or hatred for strangers; it becomes concrete in discriminatory attitudes and behaviors and often results in violence, all forms of harassment, and hate representation (Mogekwu, 2005). In some extreme events (e.g., Germany on February 19, 2020), it is seen in criminal events leading up to mass murder with "signs of a xenophobic motive" (Nine Dead in "xenophobic" Germany Bar Shootings, 2020). However, there has been little research on what causes societies or organizations to be ethnocentric or xenophobic (Duckitt, 2010).

It is possible to encounter xenophobia under a wide variety of conditions, one of which is the country where refugees are generally concentrated. The complete number of refugees in Turkey has reached 3 million 782 thousand 200 people (Immigration Administration General Directorate, 2018). Migration movements are not just a spatial and geographic change, but they also have the potential to transform the social life of the migrated (host) country (Albrecht, 1972). According to some assumptions, an overall crisis of the entire society is more related to xenophobia than with the growth of the foreign population of migrants (Imhof, 1993). In other words, the social aspects of xenophobia are more important than the quantitative issues, and leadership is one of the most important of these social aspects (Mannix \& Sauer, 2006). Social identity theory can explain one of these social aspects in organizations that members start xenophobia to outside group members who do not belong or do not have an emotional attachment that is formed with the help of the 
leaders. Organizational members may find that their social identities conflict, such as the identities of business leaders and family culture that accept negative norms as group property and members do not accept diversity (Karelaia \& Guillén, 2014; Robbins \& Judge, 2018).

Even if there is growing xenophobia in Turkey (Culik, 2015), the reasons behind the xenophobia have not been researched thoroughly in business life so far (Wimmer, 1997). Macro decisions of governments such as the development and implementation of immigrants affect xenophobia (Galloway, 2019), micromanagement in enterprises is also effective in this phenomenon. Immigrant research focuses on immigrants who are racial and ethnic minorities (e.g., Porché-Burke, 1995; Sue, 1999), the attitudes of host communities towards displaced individuals are hardly covered in the literature (Yakushko, 2009). The paternalistic managerial profiles may unify those group members who belong to the same culture. The restricted social criteria thus serve to exclude and devalue different/shifting types of member social identity in organizations (Metcalfe \& Altman, 2000). More clearly, organizational leaders especially in a specific type of cultural structure can define groups and these groups can define member identity with the result of outside inside member perspective. Consequently, this perspective will result in xenophobia thorough outsiders.

The concept of cultural difference, which is based on excluding immigrants from the core social group and dominating them, is based on the concept of 'otherization', which is formed by its dimensions, such as not being able to assimilate its essential elements and not be brought together culturally. At the national level, foreigners are carriers of a different culture with the potential to threaten the transmission of critical cultural values to developing members. However, contextual differences exist in the notion of superior identity (Ariely, 2017). Since each culture consists of a unique mix of orientations, foreigners inevitably threaten to alter the domestic culture through the introduction of new orientations. As, ethnic heritage, cultures may appear relatively fixed and distinct in the character of each nation that these stark differences of the cultures can contribute to the xenophobic perception (Master \& Roy, 2000). From this point of view, as the organizations have their single cultural marks, the unequaled identity of everyone in the organization can replace the idea of others and be used to play in the field of xenophobia (Taras, 2009). Consequently, even if different leadership processes have likely roles/styles, there are also significant differences, especially when the leadership tactics involve negative (i.e., authority) and non-work-related (i.e., involvement in employees' non-work lives) influence behaviors (Chong et al., 2018). These kinds of leadership style approaches and strategies of influence resemble a mostly paternalistic leadership style.

\section{Paternalistic Leadership}

The paternalist leader has a significant influence on the attitude and behavior of subordinates in many organizational settings (Aycan, 2015). In previous studies, paternalistic leadership has been linked to the attitudes of subordinates such as satisfaction, engagement, commitment, and organizational citizenship behaviors, and it is not focused on how paternalistic leadership can affect the emotional trust and personal initiative of subordinates (Bai et al., 2019). On the other hand, emic accounts of paternalistic leadership can be different for the subset of organizational cultures. Subtle differences and emic leadership practices dominant in certain countries or cultures may even not become apparent until a detailed behavioral analysis is undertaken (Brodbeck \& Eisenbeiss, 2014). For example, Austrian leaders displayed significantly more participative decision-making behavior at work than leaders from Finland, France, Czech Republic, Poland, and Turkey (Jago et 
al., 1998). This might open potential research that is of paternalistic leadership on xenophobia that leading by alternative ways of doing things, such as authoring leadership, collectivist setting, a leadership style which fuses the strengths of local may harm other approaches of family relations.

Paternalistic leadership consists of three dimensions: authoritarianism, benevolence, and moral leadership (Aycan et al., 2013; Farh \& Cheng, 2000; Gerçek, 2018). Authoritarianism refers to a leader's behavior that asserts absolute authority and control over subordinates and demands unquestionable obedience from subordinates, and imposes strict discipline on subordinates (Aycan et al., 2013). The authority dimension of the paternalistic leadership is based on the social deterrence theory. According to this theory, the leader can motivate compliance and order in the workplace with the threat of penalties and enforcement. Employees should act by weighing the potential gains and losses of being incompatible or negative in the workplace and seeing such behaviors by leaders. Deterrence is a necessary element of leadership. Groups and organizations cannot function if employees' behavior is not restricted according to the rules. However, studies determining the effects of the leadership model based on the deterrence theory are minimal (Tepper, 2000; Tepper et al., 2009). Benevolence dimension of the paternalistic leadership means leader's behavior demonstrates individualized, holistic concern for subordinates' personal or familial wellbeing; and morality dimension of the paternalistic leadership can be defined as leader behavior that emphasizes the pursuit of superior personal virtues through acting unselfishly, having selfdiscipline, and leading by example (Aycan et al., 2013).

Different leadership methods affect the dynamics of the groups differently (Forsyth \& Nye 2008). Leung (2001) argued that (a) people in collectivistic cultures have higher levels of unconditional benevolence and positive social identity which, in turn, lead to higher levels of ingroup involvement than is the case for people who value individualism; (b) negative reactions from supervisors in high power distance cultures generate more negative reactions among workers than is the case in low power distance cultures (Latham, 2007). In other words, organizational members may thus pick and choose which of their social identities are salient to the situation, such as the identities of the business leader (Robbins \& Judge, 2017). In such a situation, the leader is considered to be deliberate in doing the undue favor to one of his subordinates, which can be considered the other-group as so different that it must be segregated, expelled or destroyed (Banton, 1996; Cox \& Rouček, 1970). Additionally, the assimilation or acceptance of immigrants depends on the process that can be measured by the extension of family patterns (Banton, 1996; Todd, 2015) in which can be developed by paternalistic leadership in organizations. Therefore, a paternalistic leadership-like leadership style has the potential to transform the style into workplace discrimination (Aycan, 2006b; Börekçi, 2009) or vice versa.

The main features of Turkish organizational culture are mainly the acceptance of high power distance, the prevalence of autocratic and paternalist leadership styles, the lack of individualism and criticism (Berkman \& Özen, 2008). Employees consider their superiors to be "a compassionate father" and expect them to play "the role of a parent" and expect them to be protective and concerned about work and non-work matters (Pasa, 2000). Although the supervisors with paternalistic features try to establish a family-like atmosphere in the workplace and deal with their subordinates like a father (Farh \& Cheng, 2000), the expected loyalty and different paternalistic approaches may increase discrimination to xenophobia by increasing inequality (Börekçi, 2009). 


\section{Paternalistic Leadership and Xenophobia}

Leaders play a significant effect on defining organizational culture (Brodbeck \& Eisenbeiss, 2014; Klein et al., 2013; Sarros et al., 2002; Shao, 2019). Klein et al. (2013) also found that organizational effectiveness is related to the exact types of culture and that a cultural norm is, moreover, related to a specific type of leadership style. However, in companies with a detailed culture, where "policies and rules" are significant and dominant, middle managers tend to avoid using assertive influence, which involves not only demanding behavior but also threatening behavior, which may be perceived as socially unacceptable and a dark side of leadership (Bacon, 2012; Chong et al., 2018). According to this view, which is based on the discourse theory, it is the leaders who hold this power and establish this discourse of exclusion and empowerment by institutionalizing in multicultural business environments or migration policies (Wimmer, 1997). The group of social scientists claims that concepts of cultural distinctiveness, forming the essential elements of a concept of 'otherness' which helps to exclude immigrants from the core social group. Above all, it is the official or semi-official power holders who create this discourse of exclusion and selfempowerment and institutionalize it in multicultural social work or immigration policies. Ostensibly, Stephan and Stephan (2013) theorized that when individuals from the in-group perceive a supposed threat from the out-group, this conflict creates a challenge to their self-image, resulting in anxiety.

Cross-cultural research has shown that dislike and rejection of outgroups and foreigners can also be a cultural phenomenon, with certain cultures responding collectively with greater xenophobia to outsiders than others do (Duckitt, 2010). In a nutshell, xenophobia is related to several social science concepts describing different kinds of antipathy to others who may differ in almost any way, but which mostly refers to intergroup differences (Levine \& Hogg, 2010). These differences are based on seeking any denials of personal dissimilarities is resulting from selves that creates a specific vision of employees and the world to transmit it to others. However, this vision of employees may be caused by leaders rather than social media, as Bollas (2018) suggested in organizations. Conversely, Neuberg and Cottrell (2006) argue that, because situational, dispositional, and cultural contexts all interact to form separate stereotypes of different groups held by unlike people. Different leader styles may have, unlike impacts. In Turkish business, paternalistic leadership may seem more effective than other types of leadership styles (Aycan, 2015; Pellegrini \& Scandura, 2008). Based on the power owned by the leadership and its effect on defining organizational culture, the paternalistic leadership can have an impact on cultural xenophobia. In this context, the following hypothesis is developed.

Hypothesis 1: Leadership, namely paternalistic, has a significant impact on cultural xenophobia.

In contrast to cultural differences, the personal traits of individuals can cause xenophobia in organizations (Gurina, 2016). Duckitt (2010) states that dislike and rejection of outgroups and foreigners can be an individual phenomenon, and reactions to foreigners may vary widely within societies or cultures, with some people responding with hostility and others not. For example, confidential anger also causes xenophobia. Personal anger due to life difficulties and poverty arises from foreigners' anger, similar to looking for scapegoats, on the pretext that immigrants commit a crime and take away their jobs (Harris, 2001; Odiaka, 2017). Thus, in the light the discussion we propose the following hypothesis: 
Hypothesis 2: Paternalistic leadership has a positive impact on the individual dimensions of xenophobia.

As mentioned above, deterrence is a necessary element of leadership. Deterrence theory predicts that the authoritarian dimension of paternalistic leaders understands their predicted roles and respects the leader through deterrent power and threatens employees with potential punishments for their disobedience. In other words, with authoritarianism, a leader can assert absolute authority and control, insist on obedience, and impose strict discipline on subordinates (Aycan et al., 2013), which eventually evokes a stronger response of dependence and compliance (Farh \& Cheng, 2000). According to some studies authoritarian is negatively related to job performance and organizational citizenship behavior (Aryee, Chen, Sun, \& Debrah, 2007; Liang, Ling, \& Hsieh, 2007), job satisfaction and psychological well-being (Chao \& Kao, 2005). Likewise, workplaces where the authoritarian paternalistic leaders are in charge create unpleasant work outcomes, feelings of discrimination within the work environment (Erden \& Okten, 2019), social classes, and separations (Grasmick et al., 1983). In this context, our reasoning is represented in the following hypothesis:

Hypothesis 3: The authority dimension of paternalistic leadership increases xenophobia.

One of the paternalistic leadership dimensions is creating a family atmosphere, where paternalistic leaders treat employees like a family member and create a relationship as it is between the father and a son or a brother (Cheng \& Wang, 2015). Affective event theory suggests that the working environment causes certain emotions that can affect employees' attitudes and guided behavior over time (Zhao et al., 2007). However, the theory suggests that negative emotions that have cynical consequences have a more substantial effect (McColl-Kennedy \& Anderson, 2002). Considering the paternalistic leadership dimension, in fact, the benefits of creating a family atmosphere can have uncooperative effects on employees who are seen outside the family within the organization. The reason for this is that the gloomy emotions are caused by the employees within the family that can exceed their limits spread of the organization (Schwartz, 1999). It can be said that these negative emotions can highlight xenophobia over time. In this context, the fourth hypothesis is presented below:

Hypothesis 4: The dimension of paternalistic leadership to create a family atmosphere increases xenophobia.

Information processing theory explains the employees' perceptions of leadership based on social cognitive principles. The theory sees leadership as a result of social-cognitive processes that people use to label others (Üstüner Top, 2011). Inference-based processing as a derivative of information processing theory shows that followers refer to the characteristics of leaders based on the results of remarkable events (Lord, 1985). From the perspective of paternalistic leadership, the perception of individual relationships with the paternalistic leader, depending on how these relationships are interpreted and processed among other employees is important. Paternalism, as discussed before, is a kind of hierarchical relationship in which a leader guides professional and personal lives of subordinates, in exchange of loyalty and respect (Gelfand, Erez \& Aycan, 2007). Employees can think that loyalty or respect to the leader highly praised and resulting from good idiosyncratic relationships with the leader. So, if employees interpret this loyalty as their separating and discriminating features of relationship, and they can consequently behave towards other employees. Thus, in the light the discussion we propose the following hypothesis: 
Hypothesis 5: The loyalty and respect expectation dimension of paternalistic leadership is effective in reducing the xenophobia.

\section{Method}

\section{Data Collection and Sampling Procedure}

The majority of Syrians are included in the illegal and precarious workforce in the secondary labor markets, where they have poor living and working conditions to survive. Syrian immigrants work in medium-sized/under the counter companies that manufacture textiles and plastic shoes in Gaziantep organized industry to make a living. Most of the plastic shoe manufacturers are small enterprises called under the counter, and Syrian migrants who work for cheaper labor hours are employed because the state control is limited.

For this reason, plastic shoe manufacturers have been chosen as the research universe. According to the Gaziantep Chamber of Commerce data (GTO, 2019), 472 companies of various sizes have been licensed to produce plastic shoes. Currently, 78 under the counter companies are actively producing in the sector with 634 employees. For a 95\% confidence level and $\pm 5 \%$, the precision level sample size should be 242 for the population with a size of 600 (Israel, 2013). More than 500 hundred questionnaires are dispersed, but only 143 are analyzed due to respond to number is 200 and at most 143 are filled eligibly.

The research was conducted with pre-structured questionnaires. Research data covers all personnel working in enterprises producing plastic shoes, between 11 August 2019 and 02 December 2019. Questionnaires were distributed to all employees working in the plastic shoe industry. The purpose and intents of the research were explained to the participants, they were told that there are no right or wrong answers and that they can quit at any time. Besides, the researchers assured them of information confidentiality. This was done to evade the potential threats of social desirability and common method bias (Podsakoff et al., 2012).

\section{Instruments}

Paternalistic leadership scale developed and validated by Aycan (2006b) in Turkish. It is a 6-point Likert-type scale consisting of 21 items and five sub-dimensions. The sub-dimensions of the scale are a family environment in the workplace, relationships at the individual level, dealing with the lives of employees outside of work, loyalty expectation, hierarchical status, and authority (Aycan, 2006a; Pellegrini \& Scandura, 2008). This scale was revalidated by Şendoğdu and Erdirençelebi (2014) and Erol and Şentürk (2018).

Xenophobia scale developed by Veer et al. (2011) is a 6-point Likert-type scale consisting of 14 items. Xenophobia scale is a short scale that can be applied at the national level to determine the fear base xenophobia. During the scale development phase, researchers have created a pool of 30 items from different sources on the subject to develop a tool to measure xenophobia. They collected data from 193 university students from The Netherlands, 303 university students from Norway, and 608 university students from the United States with the quantitative research method. As a result of the analysis, they determined that 14 items were based on fear and that they hate, humiliate, and perceive threats against foreigners. These items include personal fear, fear of cultural change, fear of disloyalty, fear of political pain (van der Veer et al., 2011). All items were translated from English into Turkish using the back-translation approach set forth by (Brislin, 1980). The items were back-translated by two bilinguals, furthermore, an independent authorized translator retranslated the items and the translations were compared for content accuracy. A pre-test (pilot) 
study was conducted with 21 Syrian migrant employees to evaluate the presence of wording ambiguity, appropriateness, clarity, and suitability of sentence structure. Several modifications were made.

\section{Demographic Information}

The demographic data (i.e., age, gender, marital status, level of education, organizational tenure, and organizational position) of the participants in this study are presented in Table 1.

Table 1

Demographic Information of Participants

\begin{tabular}{lcc}
\hline & Frequency & Percentage \\
\hline Age & & 29.3 \\
$22-32$ & 42 & 48.3 \\
$33-43$ & 69 & 22.4 \\
$44-65$ & 32 & 100.0 \\
Total & 143 & 79.0 \\
Gender & & 21.0 \\
Male & 113 & 100.0 \\
Female & 30 & \\
Total & 143 & 27.3 \\
Marital Status & & 72.7 \\
Single & 39 & 100.0 \\
Married & 104 & 62.2 \\
Total & 143 & 27.3 \\
Education & & 10.5 \\
High/Middle school & 89 & 100.0 \\
Associate degree & 39 & 34.3 \\
Bachelor's degree & 15 & 39.9 \\
Total & 143 & 25.8 \\
Tenure & & 100.0 \\
1-3 years & 49 & \\
4-6 years & 57 & \\
6-10 years & 37 & \\
Total & 143 & \\
\hline
\end{tabular}

\section{Results and Discussion}

The model (Figure 1) is termed full (or complete) because it comprises both a measurement model and a structural model; the measurement model depicting the links between the latent variables and their observed measures (the CFA model), and the structural model depicting the links between the latent variables themselves. The GFI and AGFI can be classified as absolute indices of fit, and both indices range from zero to 1.00 , with values close to 1.00 being indicative of good fit (.897 and .874). CFI ranges from zero to 1.00 and is derived from the comparison of a hypothesized model with the independence (or null) model. Although a value $>.90$ has initially been considered representative of a well-fitting model (Hu \& Bentler, 1999), which is .934 in our research. RMSEA is expressed per degree of freedom, thus making it sensitive to the number of estimated parameters in the model (i.e., the complexity of the model); values less than .05 indicate the good fit, and values as high as .08 represent reasonable errors of approximation (Byrne, 2010; MacCallum et al., 1996) in the population which is .05 so our model seems a reasonably good fit. 


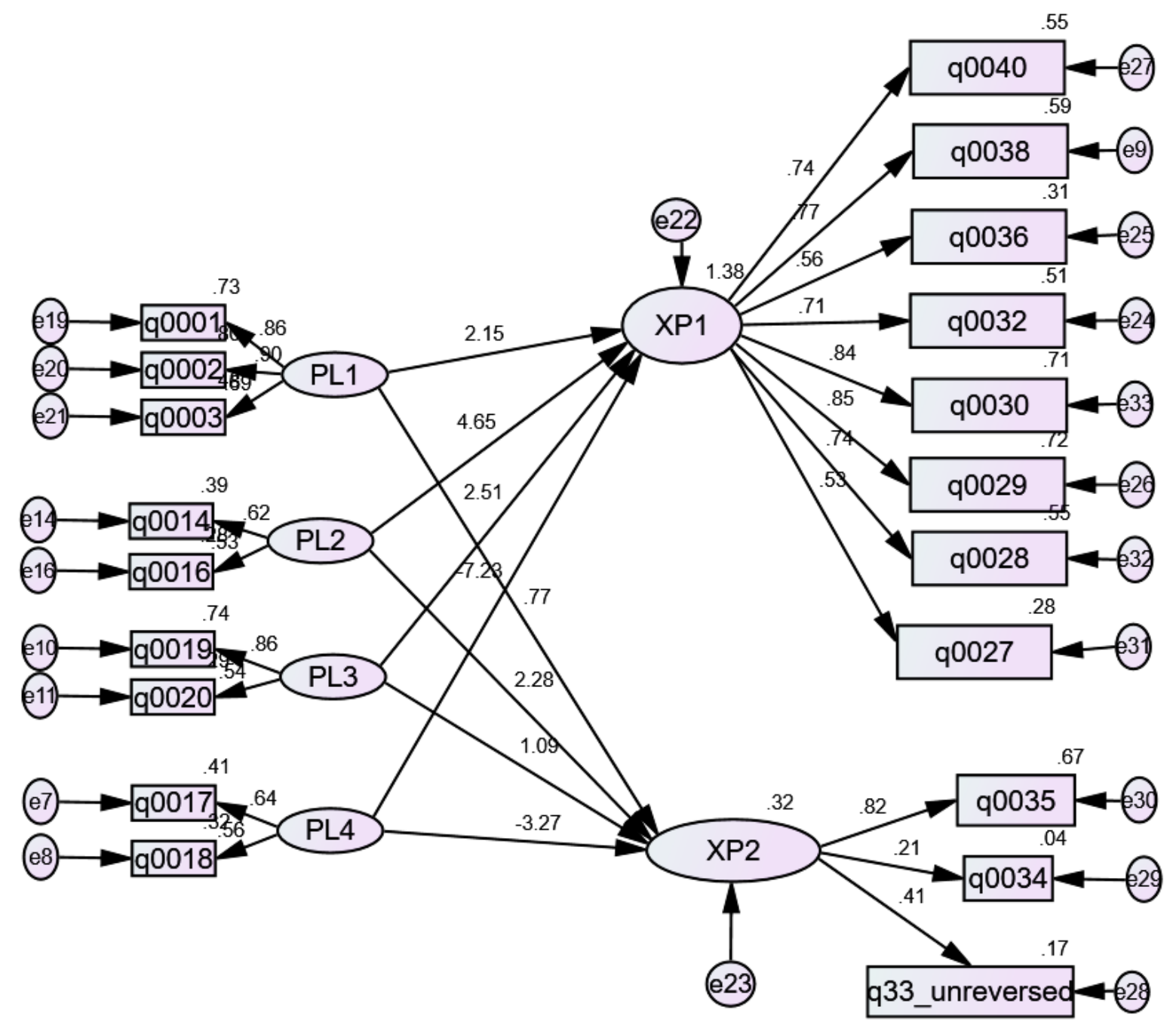

Figure 1. Standardized CFA of the work engagement scale

According to the model of the research, paternalist leadership is divided into four factors. Since the first factor (PL1) consists of family environment questions, it was called the family environment factor. PL1 factor has three questions; for example, "He advises employees like a senior family member. It consists of loyalty expectation questions such as the "PL2 factor" that expects loyalty and respect in exchange for leadership and oversight of leaders." PL3 consists of the status hierarchy and authority questions; for example, "Although it establishes close relations among the employees, it maintains its distance. Finally, PL4 again contains questions from hierarchy and authority dimension questions; it provides disciplined and also physical and emotional support (sweet and bitter).

Xenophobia questions are the measure of fear-based xenophobia. The XP1 factor is related to the cultural and identity dimensions of xenophobia, and consists of eight questions; for example, "I suspect that immigration in this country is out of control" or "I suspect that immigrants will primarily seek the interests of this country." In this respect, this factor is related to XP1, fear of cultural change, or loss of identity. The XP2 factor is about individual losses and political change, and consists of three items; for example, "I welcome interaction with immigrants" or "It is good that immigrants stay close to their cultural roots" The XP2 factor is about personal and political fear. 
The data obtained as a result of the confirmatory factor analysis were compared with the correlation analysis, and the size and direction for the relationship between each other were explored. The results are given in Table 2.

Table 2

Correlation Results

\begin{tabular}{lc|c|c|c|c|c}
\hline \multicolumn{7}{c}{ Pearson Correlations (sig. (2-tailed), N=143) } \\
\hline & PL1_MEAN & PL2_MEAN & PL3_MEAN & PL4_MEAN & XP2_MEAN & XP1_MEAN \\
\hline PL1_MEAN & 1 & $.376^{* *}$ & .086 & $.466^{* *}$ & -.031 & $.183^{*}$ \\
PL2_MEAN & $.376^{* *}$ & 1 & $.278^{* *}$ & $.449^{* *}$ & .125 & $.216^{* *}$ \\
PL3_MEAN & .086 & $.278^{* *}$ & 1 & $.378^{* *}$ & .076 & $.232^{* *}$ \\
PL4_MEAN & $.466^{* *}$ & $.449^{* *}$ & $.378^{* *}$ & 1 & .015 & .138 \\
XP2_MEAN & -.031 & .125 & .076 & .015 & 1 & $.461^{* *}$ \\
XP1_MEAN & $.183^{*}$ & $.216^{* *}$ & $.232^{* *}$ & .138 & $.461^{* *}$ & 1 \\
\hline
\end{tabular}

PL1: Family environment factor, PL2: Loyalty factor, PL3: Status hierarchy and authority factor1, PL4: Hierarchy and authority factor2, XP1: Cultural and identity dimensions of xenophobia, XP2: Personal and political fear of xenophobia.

** Correlation is significant at the 0.01 level (2-tailed).

* Correlation is significant at the 0.05 level (2-tailed).

As shown in Table 2, the PL1 (family environment) factor is positively and significantly associated with the XP1 factor. In other words, it increased the paternalistic leadership PL1 factor increases personal xenophobia. This means that the fact that employees are included in the family atmosphere do not see other members of the business as family members. PL2 (loyalty) is also positively and significantly associated with XP1. In short, loyalty to leaders constitutes xenophobia in a cultural sense. Besides, PL3 (status and hierarchy) significantly affects the XP1 factor. In other words, PL1, PL2, and PL3 factors culturally (XP1) affect the xenophobia factor positively. However, paternalistic leadership does not significantly affect the personal and political (XP2) hostility factor of xenophobia.

As a result of the study, it was determined that in the workplace, there is no individual or political xenophobia, xenophobia stem from culture and cultural origin. Hypothesis 1 has been supported (.183, $\beta=2.15)$; paternalistic leadership increases cultural xenophobia. In contrast, Hypothesis 2 was rejected (significance is $>0.05$ ); that is, there is no xenophobia caused by personal and political reasons in our country. Paternalistic leadership dimensions are in a way to further deepen this cultural alienation. This result is consistent with the study, which states that the idea of losing one's social structure and culture will have negative feelings such as sadness (Eisenbruch, 1990). In other words, studies should be carried out to bring not only economic but also cultural distances to employees (Penninx, 2005).

It has been found that the authority dimension of paternalistic leadership increases cultural xenophobia but has no effect on individual and political xenophobia, but authority is the factor that increases the cultural dimension the most $(.232, \beta=7.29)$. Since this result is new in the literature, it is crucial for the originality of the study. Loyalty and respect waiting dimensions increase the xenophobia along with authority. However, it is still not valid on individual and political xenophobia. This result shows that hypothesis 3 received partial empirical support.

The behavior of paternalistic leaders to create a "family atmosphere" increases cultural xenophobia from cultural change or loss of identity perspective, as presented in Table 2. At the same time, it does not affect individual and political aspects. Additionally, creating a family 
environment affects xenophobia to a minimum $(.183, \beta=2.15)$ (See Table 2). Hypothesis 4 (The dimension of paternalistic leadership to create a family atmosphere increases xenophobia); therefore, is partly supported. These results are contradicting with the individual context zone concept. Based on the concept of a contact zone, Ahmed (2000) stated that the singular experiences of "foreigners" can be a contact point that can be both personal and collectively transformant. Pratt (1991) proposed the concept of the contact zone, which invites individuals to focus on differences, subjectivity, questioning capacity, and ability to recognize conflicts. However, leadership is not effective on the employee level; instead of leaders should focus on organization culture and employee identity for integration (Yukl, 2013). These results show that even if integration lasted for decades and related to unions, liberalization of university access, and increased mixed marriages of the second generation culture and identity issues can be solved at the organizational level that the evident aspects of xenophobia may decline steadily.

Loyalty expectations also positively correlated $(.216, \beta=4,65)$ that these expectations are increasing the xenophobia of cultural and identity aspects more than the family factor of leadership. As a result, Hypothesis 5 is rejected. This result is coherent with the research that in Europe, xenophobia and authoritarian orientations are related (Levine \& Hogg, 2010). Loyalty or respect expectations may functionally mask stereotypic perceptions of incompetence that convey a lack of respect (Henry \& Pratto, 2010). Uncertainty-identity theory also supports our findings. This theory implies that identity is a process that not only defines and locates oneself in the social world but also prescribes how one should behave and how one should interact with others (Hogg, 2010; Hogg $\&$ Terry, 2000). So, being in a family atmosphere is equally important defined how the employees may act, and loyalty/respect expectations as a part of that process may increase cultural and identity xenophobia.

\section{Conclusion}

This paper studied the effects of leadership, paternalistic, on xenophobia in organizations from contextual perspective. Leaders have the power to affect both context and individual behaviors that individual behavior is shaped dramatically either positively or negatively. Therefore, leaders must pay special attention to roles, norms, and cohesion - to understand how these are operating within a group is to understand how the group is likely to behave. To decrease the possibility of the xenophobic workplace and social activities, leaders must ensure that group norms do not support antisocial behavior. However, some type of leadership may cause xenophobia unintentionally in a related type of culture.

To provide a comprehensive understanding of the phenomenon, this article empirically investigates the potential effects of paternalistic leadership on xenophobia. Our findings revealed that paternalistic leadership has a negative impact on humanizing integration and the identity of xenophobia. It is impossible to consider the employment problems of asylum-seekers separately from the social, political, cultural, and legal factors affecting this process. In addition to its economic features, the subject attracts attention with its human aspect. Leaders are one of the most influential aspects of employees and strategy in the organization (Hambrick, 2007; Hambrick \& Mason, 1984; Shao, 2019). Nevertheless, the effect of leadership is context-specific (Chong et al., 2018; Liu et al., 2010) that each leadership behavior or style can have a unique impact on different organizations. Our investigation shows that paternalistic leadership has a significant impact on the cultural and identity dimensions of xenophobia self-idealization. 
In today's dynamic environment, controlling and reducing the xenophobic attitudes has become essential in obtaining sustainable competitive advantage. In this context, it is an indispensable for businesses to reduce xenophobia and to increase business performance. Identifying the antecedents of xenophobia, which is of critical importance for business life, is also critical in this respect. According to several researchers understanding the antecedents of xenophobia is important (Ariely, 2017; Duckitt, 2010; Master \& Roy, 2000; van der Veer et al., 2011; Yakushko, 2009).

This paper advances the field by adopting an organizational perspective of xenophobia, in particular, by integrating and examining the impact of paternalistic leadership. Drawing from the social identity theory, we advanced and tested a theoretical model that delineates the effects of paternalistic leadership on xenophobia. In line with our assertions, the findings denote that employee perceptions of the paternalistic leadership results in xenophobia. This makes intuitive sense, as paternalistic leadership is likely to trigger unwanted behavior such as xenophobia. The results of this study would clearly help in avoiding the detrimental effects of xenophobia caused by the paternalistic leadership, and it definitely has theoretical and practical implications for managers and organizations.

In terms of organizational behavior and theoretical contributions the results obtained have shown that paternalistic leadership has a significant impact on the cultural and identity dimensions of xenophobia self-idealization, which clearly indicates that leadership style chosen, in our case paternalistic leadership, is a substantial tool to be used in favor of the organization. It is clearly understood that specific cultural constructs are needed in paternalistic leadership which can be explained by prescription view rather than descriptive view in which broad meta-leadership categories are researched. Additionally, by examining the dynamics of a sample in Turkey, appropriate to the research context, this study has constituted steps to sail new horizons in this regard. In terms of organizational practical implications contributions, we refined the national-level phenomenological approach to be organizational-level. The decline in wages with the arrival of Syrians deepens the unemployment problem of workers, especially those living in the region where asylum seekers are concentrated. Workers complain about not finding a job. As a result of being a foreigner, it is a frequent problem for refugees to be seen as a scapegoat in various negativities, especially unemployment and wide-ranging. Some of the citizens see immigrants as the reason for the negativities that occur in living conditions (Koç et al., 2015). However, this perspective is not resulting from a rising criminalization by the political system (Palidda \& Fondazione, 2001) in Turkey.

Employees in Turkey are waiting to establish close and often personal relationships with leaders and vice versa. This demand turns from the leaders of the employees to the expectation of creating a family atmosphere in the workplace. However, not being careful in the distribution of authority and benevolence may reveal employment discrimination arguments (Erden \& Okten, 2019). Consequently, these arguments may bring hostility towards foreign workers because social, political, economic, and individual origins of xenophobia are intertwined.

The right or wrong definition of the media and the public as the perpetrators of both minor crimes and the most disgusting crimes affected the society, and these accusations, which were generally unfounded and exaggerated, were directed to the Italian "Southerners" in the 1950s and 1960sgeneralized to incoming foreigners (Dotti, 2020). Similarly, immigrants living in Turkey are faced with the danger of being targeted in internal disputes about national identity. Although Turkish society does not have enough experience to live with immigrants outside the cosmopolitan city of 
Istanbul, complaints, and frictions, have not yet reached mass proportions. Complaints and frictions occur mostly in regions where Syrian refugees such as Gaziantep, Şanlıurfa, Adana, and Mersin live. Reactions to foreigners have the potential to spread across the country over time (Çetin, 2016). Xenophobia intertwines social, political, economic, and individual origins. It has threatened people's lives and livelihoods. On the other hand, studies to solve the problem in working life are limited in our literature.

Enterprises should lay the foundations for eliminating cultural differences in management understanding. In line with the conceptual suggestions described above, leaders should treat newcomers as family members, and expand their loyalty and respect framework not only to themselves but also to other individuals. On the other hand, instead of authoritarian concepts within the family, they can establish collective decision-making mechanisms suitable for the Turkish business culture and create contact points between newcomers and existing employees. Political, social, and cultural leaders must decisively condemn the manifestations of racism and xenophobia to respect all people working in the same workplace and to create an environment of peace.

Besides these findings, this empirical work inherits several limitations which provide several opportunities for future research. Firstly, the study's data is obtained from a single area (Gaziantep) source using a cross-section design, which limits causal inference. On this account, we recommend future work in this research stream to utilized multi-sourced, time-lag and experimental design to draw a causal inference. Secondly, the study data came from a single country and context which limits generalizability and applicability of findings to other countries, industries, and contextual settings. On this account, we recommend future work in this research stream to replicate this study.

\section{Declarations of Interest}

None.

\section{Funding}

This research did not receive any specific grant from funding agencies in the public, commercial, or not-for-profit sectors.

\section{References}

Ahmed, S. (2000). Strange encounters: Embodied others in post-coloniality. Routledge.

Albrecht, G. (1972). Soziologie der geographischen Mobilität: Zugleich ein Beitrag zur Soziologie des sozialen Wandels. F. Enke.

Ariely, G. (2017). Global identification, xenophobia and globalisation: A cross-national exploration: Globalization and global identification. International Journal of Psychology, 52, 87-96. https://doi.org/10/ggm8zd

Aryee, S., Chen, Z. X., Sun, L. Y., \& Debrah, Y. A. (2007). Antecedents and outcomes of abusive supervisor: test of a trickledown model. Journal of Applied Psychology, 1, 191-201.

Asia-Pacific, N. (2001). Declaration on racism, discrimination, xenophobia and related intolerance against migrants and trafficked persons. Paper presented at the World Conference Against Racism, Racial Discrimination, Xenophobia and Related Intolerance. Tehran, Iran, February, 18.

Aycan, Z. (2006a). Paternalism. In U. Kim, K. S. Yang, \& K. K. Hwang (Eds.), Indigenous and cultural psychology (pp. 445466). Springer US. https://doi.org/10.1007/0-387-28662-4_20 
Aycan, Z. (2006b). Paternalism: Towards conceptual refinement and operationalization. In Ŭ. Kim (Ed.), Indigenous and cultural psychology: Understanding people in context (pp. 445-466). Springer.

Aycan, Z. (2015). Paternalistic leadership. In C. L. Cooper (Ed.), Wiley encyclopedia of management (pp. 1-2). John Wiley \& Sons, Ltd. https://doi.org/10.1002/9781118785317.weom060156

Aycan, Z., Schyns, B., Sun, J. M., Felfe, J., \& Saher, N. (2013). Convergence and divergence of paternalistic leadership: A crosscultural investigation of prototypes. Journal of International Business Studies, 44(9), 962-969. https://doi.org/10/ggbmzv

Bacon, T. R. (2012). Elements of influence: The art of getting others to follow your lead. American Management Association.

Bai, S., Lu, F., \& Liu, D. (2019). Subordinates' responses to paternalistic leadership according to leader level. Social Behavior and Personality: An International Journal, 47(11), 1-14. https://doi.org/10/ggkdmf

Banton, M. (1996). The cultural determinants of xenophobia. Anthropology Today, 12(2), 8. https://doi.org/10/fgqcrt

Berkman, Ü., \& Özen, Ş. (2008). Culture and management in Turkey: State-dependency and paternalism in transition. In E. Davel, J. P. Dupuis, \& J. F. Chanlat (Eds.), Gestion en contexte interculturel: Approches, problématiques, pratiques et plongées (pp. 6.4:1-25). Quebec: Les Presses de l'Universite Laval.

Bollas, C. (2018). Meaning and melancholia: Life in the age of bewilderment. Routledge.

Börekçi, D. Y. (2009). Paternalistic leadership style's evolution in e-culture. Istanbul University Journal of the School of Business Administration, 38(2), 103-109.

Brislin, R.W. (1980). Translation and content analysis of oral and written materials. Methodology, 389-444.

Brodbeck, F. C., \& Eisenbeiss, S. (2014). Cross-cultural and global leadership. Oxford University Press. https://doi.org/10.1093/oxfordhb/9780199755615.013.032

Byrne, B. M. (2010). Structural equation modeling with AMOS basic concepts, applications, and programming. Routledge.

Chao, A. A., \& Kao, H. S. R. (2005). Paternalistic leadership and subordinate stress in Taiwanese enterprises. Research in Applied Psychology, 27, 111-131.

Cheng, M. Y., \& Wang, I. (2015). The mediating effect of ethical climate on the relationship between paternalistic leadership and team identification: A team level analysis in the Chinese context. Journal of Business Ethics, 129, 639-654.

Chong, M. P. M., Shang, Y., Richards, M., \& Zhu, X. (2018). Two sides of the same coin? Leadership and organizational culture. Leadership \& Organization Development Journal, 39(8), 975-994. https://doi.org/10/gff5fj

Clark, R., Anderson, N. B., Clark, V. R., \& Williams, D. R. (1999). Racism as a stressor for African Americans: A biopsychosocial model. American Psychologist, 54(10), 805-816. https://doi.org/10/df7srj

Cox, O. C., \& Rouček, J. S. (1970). Caste, class and race: A study in social dynamics (First modern reader paperback edition). Modern Reader Paperbacks.

Culik, J. (2015). Anti-immigrant walls and racist tweets: the refugee crisis in central Europe. In Conversation (Vol. 2015, p. 24).

Çetin, İ. (2016). Suriyeli mültecilerin işgücüne katılımları ve entegrasyon: Adana-Mersin Örneği [Labor force participation and integration of Syrian refugees: The Adana-Mersin case]. Gaziantep University Journal of Social Sciences, 15(25129), 10011016. https://doi.org/10.21547/jss.265320

Dennen, J. M. G. van der. (2000). Of badges, bonds and boundaries: Ingroup/outgroup differentiation and ethnocentrism revisited. NJCM Boekerij.

Dotti, G. (2020). Racism, xenophobia, and migration in Italy, a Post-Catholic country. The Ecumenical Review, 72(1), 37-47. https://doi.org/10/ggkdmk

Duckitt, J. (2010). Xenophobia. In J. M. Levine \& M. A. Hogg (Eds.), Encyclopedia of group processes \& intergroup relations (pp. 958-961). SAGE Publications.

Eisenbruch, M. (1990). The Cultural bereavement interview: A new clinical research approach for refugees. Psychiatric Clinics of North America, 13(4), 715-735. https://doi.org/10/ggj8f3

Erden, P., \& Okten, A. B. (2019). The dark side of paternalistic leadership: Employee discrimination and nepotism. European Research Studies Journal, XXII,(2), 154-180. https://doi.org/10/ggj8f5

Erol, E., \& Şentürk, I. (2018). Paternalistic leadership scale Turkish adaptation a validity - reliability study. International Journal of Educational Methodology, 4(4), 267-285. doi: 10.12973/ijem.4.4.267 
Farh, J. L., \& Cheng, B.-S. (2000). A cultural analysis of paternalistic leadership in Chinese organizations. In J. T. Li, A. S. Tsui, \& E. Weldon (Eds.), Management and organizations in the Chinese context (pp. 84-127). Palgrave Macmillan UK. https://doi.org/10.1057/9780230511590_5

Forsyth, D. R., \& Nye, J. L. (2008). Seeing and being a leader: The perceptual, cognitive, and interpersonal roots of conferred influence. In C. L. Hoyt, G. R. Goethals, \& D. R. Forsyth (Eds.), Leadership at the crossroads: Leadership and Psychology (Vol. 1, pp. 116-131). Westport, CN: Praeger.

Galloway, D. (2019). Immigration, xenophobia and equality rights. Dalhousie LJ, 42, 17.

Gaziantep Chamber of Commerce (2019). https://www.gto.org.tr/en.html. (Date of access: 07 January 2020).

Gelfand, M. J., Erez, M., \& Aycan, Z. (2007). Cross-cultural organizational behavior. Annual Review of Psychology, 58, 479-514.

Gerçek, M. (2018). Yöneticilerin babacan (Paternalist) liderlik davranışlarının psikolojik sözleşme bağlamındaki beklentileri üzerindeki etkilerine yönelik bir çalışma [A study on the effects of managers' paternalistic leadership behaviors on their expectations in the context of psychological contracts]. Eskişehir Osmangazi Üniversitesi İktisadi ve İdari Bilimler Dergisi [Eskişehir Osmangazi University Journal of Economics and Administrative Sciences], 13(2), 101-118. https://doi.org/10/ggj8f4

Graen, G. (2005). Vertical dyad linkage and leader-member exchange theory. Chair in Human Resources at the State University of New York-Buffalo and Was Faculty Director of the Center for Entrepreneurial Leadership There. Previously He Was Research Professor of Management at Georgia State University. He Has Written over Fifty Books and over 135 Other Publications., 256.

Grasmick, H. G., Jacobs, D., \& McCollom, C. B. (1983). Social class and social control: An application of deterrence theory. Social Forces, 62(2), 359-374. https://doi.org/10/d3f7p8

Guimond, S. (2000). Group socialization and prejudice: The social transmission of intergroup attitudes and beliefs. European Journal of Social Psychology, 30(3), 335-354. https://doi.org/10/djc2wr

Gurina, O. D. (2016). Xenophobic attitudes and personal characteristics of adolescents with deviant behaviour. Psychology and Law, 6, 39-57. https://doi.org/10/ggj82n

Hambrick, D. C. (2007). Upper echelons theory: An update. The Academy of Management Review, 32(2), $334-343$. https://doi.org/10/fpkxx2

Hambrick, D. C., \& Mason, P. A. (1984). Upper echelons: The organization as a reflection of its top managers. The Academy of Management Review, 9(2), 193-206. https://doi.org/10/dfqwzd

Harris, B. (2001). A Foreign Experience: Violence, Crime and Xenophobia During South Africa's Transition. CSVR. Violence and Transition Series, 5. https://books.google.com.tr/books?id=vFd0AAAAMAAJ

Haslam, S. A., \& van Dick, R. (2011). A social identity approach to workplace stress. Social Psychology and Organizations, 325352.

Henry, P. J, \& Pratto, F. (2010). Power and racism. In A. Guinote \& T. Vescio (Eds.), The social psychology of power (pp. 341362). New York: Guilford.

Hogg, M. (2010). Uncertainty-identity theory. In J. M. Levine \& M. A. Hogg (Eds.), Encyclopedia of group processes \& intergroup relations (pp. 943-945). SAGE Publications.

Hogg, M. A. (2001). A social identity theory of leadership. Personality and Social Psychology Review, 5(3), 184-200. https://doi.org/10/dp4jjb

Hogg, M. A., \& Terry, D. J. (2000). Social identity and self-categorization processes in organizational contexts. The Academy of Management Review, 25(1), 121-140. https://doi.org/10/bvgm6m

Hu, L., \& Bentler, P. M. (1999). Cutoff criteria for fit indexes in covariance structure analysis: Conventional criteria versus new alternatives. Structural Equation Modeling: A Multidisciplinary Journal, 6(1), 1-55. https://doi.org/10/dbt

Imhof, K. (1993). Nationalismus, nationalstaat und minderheiten: Zu einer soziologie der minoritäten [Nationalism, nation-state and minorities: A sociology of minorities]. Soziale Welt, 44(3), 327-357.

Immigration Administration General Directorate (2018). Yıllık Göç Raporları. https://www.goc.gov.tr/yillik-goc-raporlari. (Date of access: 07 January 2020).

Israel, G. D. (2013). Determining sample size 1. University of Florida, 1-5. 
Jago, A., Reber, G., Auer-Rizzi, W., \& Szabo, E. (1998). Führungsstile in sieben ländern Europas-Ein interkultureller vergleich [Leadership styles in seven European countries - An intercultural comparison]. Personalmanagement in Europa, Stuttgart: Poeschel, 127-239.

Jost, J. T., Banaji, M. R., \& Nosek, B. A. (2004). A decade of system justification theory: Accumulated evidence of conscious and unconscious bolstering of the status quo. Political Psychology, 25(6), 881-919. https://doi.org/10/bzsh4q

Karelaia, N., \& Guillén, L. (2014). Me, a woman and a leader: Positive social identity and identity conflict. Organizational Behavior and Human Decision Processes, 125(2), 204-219. https://doi.org/10/bnfg

Klein, A. S., Wallis, J., \& Cooke, R. A. (2013). The impact of leadership styles on organizational culture and firm effectiveness: An empirical study. Journal of Management \& Organization, 19(3), 241-254.

Koç, M., Görücü, İ., \& Akbiyik, N. (2015). Suriyeli siğinmacilar ve istihdam problemleri [Syrian refugees and employment problems]. Birey ve Toplum Sosyal Bilimler Dergisi [Journal of Individual and Society Social Sciences], 5(1), 63. https://doi.org/10.20493/bt.96676

Kwantes, C. T., \& Glazer, S. (2017). Organizations and culture. In C. T. Kwantes \& S. Glazer (Eds.), Culture, Organizations, and Work (pp. 45-66). Springer International Publishing. https://doi.org/10.1007/978-3-319-47662-9_4

Latham, G. P. (2007). Work motivation: History, theory, research, and practice. Sage Publications.

Leung, K. (2001). Different carrots for different rabbits: Effects of individualism-collectivism and power distance on work motivation. In M. Erez, U. Kleinbeck, \& H. Thierry (Eds.), Work motivation in the context of a globalizing economy (pp. 329339). Lawrence Erlbaum Associates Publishers.

Levine, J. M., \& Hogg, M. A. (Eds.). (2010). Encyclopedia of group processes \& intergroup relations. SAGE Publications.

Liang, S. K., Ling, H. C., \& Hsieh, S. Y. (2007). The mediating effects of leader-member exchange quality to influence the relationships between paternalistic leadership and organizational citizenship behaviors. Journal of American Academy of Business, 10, 127-137.

Liu, L., Feng, Y., Hu, Q., \& Huang, X. (2010). Understanding individual level ERP assimilation: A multi-case study. 2010 43rd Hawaii International Conference on System Sciences, 1-10.

Lord, R. G. (1985). An information processing approach to social perceptions, leadership and behavioral measurement in organizations. Research in Organizational Behavior, 7(1), 87-128.

MacCallum, R. C., Browne, M. W., \& Sugawara, H. M. (1996). Power analysis and determination of sample size for covariance structure modeling. Psychological Methods, 1(2), 130-149. https://doi.org/10/b89fmw

Mannix, E. A., \& Sauer, S. J. (2006). Status and power in organizational group research: Acknowledging the pervasiveness of hierarchy. Advances in Group Processes, 23, 149-182. https://doi.org/10.1016/S0882-6145(06)23006-6

Master, S. D., \& Roy, M. K. L. (2000). Xenophobia and the European Union. Comparative Politics, 32(4), $419-436$. https://doi.org/10/c63fpv

McColl-Kennedy, J. R., \& Anderson, R. D. (2002). Impact of leadership style and emotions on subordinate performance. The Leadership Quarterly, 13(5), 545-559. https://doi.org/10/cd5k7p

Metcalfe, B., \& Altman, Y. (2000). Leadership. In E. M. Wilson (Ed.), Organisational behaviour reassessed: The impact of gender (pp. 104-128). SAGE.

Mogekwu, M. (2005). African Union: Xenophobia as poor intercultural communication. Ecquid Novi: African Journalism Studies, 26(1), 5-20. https://doi.org/10/c6wq73

Morén-Alegret, R. (2002). Integration and resistance. The relation of social organisations, global capital, governments and international immigration in Spain and Portugal. Routledge.

Morén-Alegret, R., \& Wladyka, D. (2020). International immigration, integration and sustainability in small towns and villages: socio-territorial challenges in rural and semi-rural Europe. Palgrave Macmillan UK. https://doi.org/10.1057/978-1-13758621-6

Neuberg, S. L., \& Cottrell, C. A. (2006). Evolutionary bases of prejudices. Evolution and Social Psychology, 163-187.

Neuman, L. W. (2014). Basics of social research: Qualitative \& quantitative approaches. Pearson Education Limited.

Nine dead in "xenophobic" Germany bar shootings. (2020, February 20). RFI. http://www.rfi.fr/en/europe/20200220-nine-deadgerman-shooting-near-frankfurt-xenophobia-kurds 
Odiaka, N. (2017). The face of violence: rethinking the concept of xenophobia, immigration laws and the rights of non-citizens in south Africa. BRICS Law Journal, 4(2), 40-70. https://doi.org/10/ggj83p

Palidda, S., \& Fondazione, I. (2001). Devianza e vittimizzazione tra i migranti [Deviance and victimization among migrants]. Fondazione Cariplo per le Iniziative e lo Studio Sulla Multietnicità [Cariplo Foundation for Initiatives and the Study on Multiethnicity].

Pasa, S. (2000). Leadership influence in a high power distance and collectivist culture. Leadership \& Organization Development Journal, 21(8), 414-426. https://doi.org/10.1108/01437730010379258

Pellegrini, E. K., \& Scandura, T. A. (2008). Paternalistic leadership: A review and agenda for future research. Journal of Management, 34(3), 566-593. https://doi.org/10/cxxsw7

Penninx, R. (2005). Integration of migrants: Economic, social, cultural and political dimensions. The New Demographic Regime: Population Challenges and Policy Responses, 5, 137-152.

Podsakoff, P. M., MacKenzie, S. B., \& Podsakoff, N. P. (2012). Sources of method bias in social science research and recommendations on how to control it. Annual Review of Psychology, 63, 539-569.

Porché-Burke, L. (1995). Review of Women of color: Integrating ethnic and gender identities in psychotherapy. Psychotherapy: Theory, Research, Practice, Training, 32(2), 367-368. https://doi.org/10.1037/h0092338

Reicher, S., Haslam, S. A., \& Hopkins, N. (2005). Social identity and the dynamics of leadership: Leaders and followers as collaborative agents in the transformation of social reality. The Leadership Quarterly, 16(4), 547-568. https://doi.org/10/bsrvd9

Robbins, S. P., \& Judge, T. A. (2017). Organizational behavior (Edition 17, global edition). Pearson.

Robbins, S. P., \& Judge, T. A. (2018). Essentials of organizational behavior (14. ed., global ed). Pearson.

Sarros, J. C., Gray, J., \& Densten, I. L. (2002). Leadership and its impact on organizational culture. International Journal of Business Studies, 10(2), 1-26.

Schwartz, S. H. (1999). A theory of cultural values and some implications for work. Applied Pychologyy: An International Review, 48(1), 23-47.

Shao, Z. (2019). Interaction effect of strategic leadership behaviors and organizational culture on IS-Business strategic alignment and Enterprise Systems assimilation. International Journal of Information Management, 44, 96-108. https://doi.org/10/ggm8tg

Sheridan, L. P. (2006). Islamophobia Pre- and Post-September 11th, 2001. Journal of Interpersonal Violence, 21(3), 317-336. https://doi.org/10/ff8q8p

Smith, P. B., Peterson, M. F., Ahmad, A. H., Akande, D., Andersen, J. A., Ayestaran, S., Bellotto, M., Bochner, S., Callan, V., Davila, C., Ekelund, B., François, P. H., Graversen, G., Harb, C., Jesuino, J., Kantas, A., Karamushka, L., Koopman, P., Leung, K., ... Yanchuk, V. (2005). Demographic effects on the use of vertical sources of guidance by managers in widely differing cultural contexts. International Journal of Cross Cultural Management, 5(1), 5-26. https://doi.org/10/c57wg9

Stephan, W. S., \& Stephan, C. W. (2013). An integrated threat theory of prejudice. Reducing Prejudice and Discrimination, 3356.

Sue, S. (1999). Science, ethnicity, and bias: Where have we gone wrong? American Psychologist, 54(12), $1070-1077$. https://doi.org/10.1037/0003-066X.54.12.1070

Şendoğdu, A. \& Erdirençelebi, M. (2014). Paternalist liderlik ile örgütsel vatandaşlık arasındaki ilişkiye yönelik bir araştırma [A research on the relationship between paternalist leadership and organizational citizenship]. Selçuk Üniversitesi I.I.I.B.F. Sosyal ve Ekonomik Araştırmalar Dergisi [Selçuk University Faculty of Economics and Administrative Sciences Journal of Social and Economic Research], 27, 254-273.

Tajfel, H., Billig, M. G., Bundy, R. P., \& Flament, C. (1971). Social categorization and intergroup behaviour. European Journal of Social Psychology, 1(2), 149-178. https://doi.org/10/b36r7b

Taras, R. (2009). Europe old and new transnationalism, belonging, xenophobia. Rowman \& Littlefield.

Tepper, B. J. (2000). Consequences of abusive supervision. Academy of Management Journal, 43(2), 178-190.

Tepper, B. J., Carr, J. C., Breaux, D. M., Geider, S., Hu, C., \& Hua, W. (2009). Abusive supervision, intentions to quit, and employees' workplace deviance: A power/dependence analysis. Organizational Behavior and Human Decision Processes, 109(2), 156-167. https://doi.org/10/cxqnkm

Todd, E. (2015). Who is Charlie? Xenophobia and the new middle class (English edition). John Wiley \& Sons..

Turner, J. C., Brown, R. J., \& Tajfel, H. (1979). Social comparison and group interest in ingroup favouritism. European Journal of Social Psychology, 9(2), 187-204. https://doi.org/10/c9hj4g 
Uhl-Bien, M., Osborn, R., \& Schermerhorn, J. R. (2014). Organizational Behavior: Experience grow contribute. 222 Rosewood Drive, Danvers, MA 01923: Clearance Center.

Üstüner Top, F. (2011). Ergenlerde sağlı̆̆ geliştirme modeli ve bilgi işlem kuramına temellendirilen hemşirelik girişiminin ă̆ız diş sağll $\breve{l}$ davranışına etkisi [Adolescent health promotion model and the impact of oral health behavior of nursing intervention applied to the information proccessing theory] (Unpublished Doctoral dissertation). Marmara Üniversitesi / Sağlık Bilimleri Enstitüsü / Çocuk Sağlı̆̆ ve Hastalıkları Hemşireliği Anabilim Dalı.

van der Veer, K., Yakushko, O., Ommundsen, R., \& Higler, L. (2011). Cross-national measure of fear-based xenophobia: Development of a cumulative scale. Psychological Reports, 109(1), 27-42. https://doi.org/10/cr59x9

Wimmer, A. (1997). Explaining xenophobia and racism: A critical review of current research approaches. Ethnic and Racial Studies, 20(1), 17-41. https://doi.org/10/ct2qfd

Yakushko, O. (2009). Xenophobia: Understanding the roots and consequences of negative attitudes toward immigrants. The Counseling Psychologist, 37(1), 36-66. https://doi.org/10/d37mn8

Yammarino, F. (2013). Leadership: Past, present, and future. Journal of Leadership \& Organizational Studies, 20(2), $149-155$. https://doi.org/10/gdtmw2

Yukl, G. (2013). Leadership in organizations. Pearson Educations Inc.

Zhao, H., Wayne, S. J., Glibkowski, B. C., \& Bravo, J. (2007). The impact of psychological contract breach on work-related outcomes: A meta-analysis. Personnel Psychology, 60(3), 647-680. https://doi.org/10/ccdp32 